\title{
PEMBANGUNAN KESATUAN DOGMA DAN POLITIK \\ DALAM PIAGAM MADINAH
}

\author{
Oleh : A. Miftahul Amin ${ }^{1}$
}

Email : a.miftahulamin@gmail.com

\begin{abstract}
ABSTRAK
Perkembangan suatu masyarakat tidak terlepas dari sistem norma dalam masyarakat itu, seperti Islam, Kristen, ataupun Yahudi, dari awal perjalanannya tidak terlepas dari sistem norma dalam instrumen wahyu dan instrumen kerasulan yang didalamnya terdapat prinsip-prinsip ajaran agama, sistem sosial, budaya dan politik yang terimplementasi dalam interaksi sosial yang melekat dalam suatu wilayah, dari sistem sosial inilah maka akan melahirkan sistem prilaku. Dengan demikian perbedaan dogma yang menjadi norma dalam suatu masyarakat akan melahirkan prilaku politik dan sosial yang berbeda-beda.

Berangkat dari pemikiran diatas memunculkan suatu asumsi baru, bahwa perbedaan suatu dogma akan melahirkan perbedaan dalam sistem sosial dan sistem politik seperti yang disaksikan dalam perkembangan sosial dan politik dari berbagai negara. penelitian ini ingin menunjukkan bahwa perbedaan dogma dalam sistem sosial dan sistem politik mampu melahirkan kesatuan dalam praktek politik dalam suatu negara. Hal ini yang mengispirasi penulis untuk mengkaji Piagam Madinah sebagai suatu konstitusi bagi masyarakat yang berbeda-beda dalam dogma, tetapi mampu membangun suatu sistem politik (negara) dalam kesatuan praktek-praktek politik. Bagaimana perbedaan dogma melahirkan kesatuan dalam Piagam Madinah ?, Nilai-nilai apa saja yang menjadi pijakan masyarakat dalam Piagam Madinah ?, Bagaimana proses pembangunan wawasan kebangsaan dalam Piagam Madinah ?.

Penelitian ini merupakan penelitian pustaka (library research). Data dikumpulkan dari berbagai literatur, baik yang bersumber dari perpustakaan maupun dari internet (website) yang berhubungan dengan Dogma dan Politik dalam Piagam Madinah.
\end{abstract}

\footnotetext{
${ }^{1}$ Penulis adalah Dosen Tetap di Sekolah Tinggi Agama Islam (STAI) Taruna Surabaya, Alumnus dari Universitas Islam Negeri Sunan Kalijaga Yogyakarta, dan Menjabat sebagai Presiden Ikatan Penulis dan Peneliti Indonesia (IPPI).
} 
Penelitian ini bersifat deskriptif analitis yakni data dogma dan politik dalam Piagam Madinah, disusun sesuai dengan fokus penelitian dan dianalisa dengan teori yang memiliki korelasi. Pendekatan dalam penelitian ini adalah normatif-filosofis yakni data di relevansikan dengan teks teori motif dan teori Maqasid Syariah.

Hasil penelitian ini adalah, Pertama, Proses Pembangunan Kesatuan dalam perbedaan dogma dan politik dalam Piagam Madinah diawali dari Muhammad Rasulullah untuk pertama kali mendapat pengakuan sebagai pemimpin dan kelompok penduduk Madinah pada Baiat 'Aqabat Pertama (621 M) dan Baiat 'Aqaba/ Kedua (622 M). Dalam ikrar baiat itu, selain pengakuan tersebut dan keimanan kepada beliau sebagai Rasul Allah serta penerimaan Islam sebagai. agama mereka, terdapat juga pernyataan kesetiaan, ketaatan, dan penyerahan kekuasaan kepada beliau. Posisinya ini kemudian menjadi kuat setelah di Madinah. Ini tampak dalam langkah beliau yang mampu mengendalikan orang-orang Islam Muhajirin dan Ansar secara nyata dan efektif dengan mempersaudarakan mereka dan membuat kesepatakan dengan suku, agama yang ada di dalam Masyarakat Madinah yang disebut Piagam Madinah. Langkah inilah sejalan dalam teori motif bahwa Mihammad Rasulullah bergabung dalam suatu masyarakat, kostruk pemikiran sejalan dengan Rasulullah yang sesuai dengan prinsip-prinsip Islam untuk masa depan masarakat yang mempunyai satu kesatuan dengan pencapaian Piagam madinah, maka dari situlah lahir prilaku yang sejalan dengan konstruk pemikiran yang dibawa oleh Muhammad SAW.

Kedua, Nilai-nilai yang menjadi pijakan masyarakat dalam pembentukan Piagam Madinah yang paling mendasar adalah hak atas kebebasan beragama, hak atas persamaan di depan hukum. hak untuk hidup, dan hak memperoleh keadilan. Sedangkan secara keseluruhan nilai-nilai dalam Piagam Madinah dalam pembangunan politik pemerintahan adalah pembentukan umat, hak asasi manusia, persatuan seagama, persatuan segenap warga negara, melindungi golongan minoritas, mengatur warga negara, melindungi negara, pimpinan negara, politik perdamaian, dan kesepakatan bersama. Hal ini sejalan dengan teori Maqasid Syariah yang bersifat daruriyat (keniscayaan) yaitu perlindungan agama, 
perlindungan jiwa, perlindungan harta, perlindungan akal, perlindungan keturunan.

Ketiga, Masyarakat Madinah merupakan komunitas heterogen yang terdiri atas berbagai suku, kepercayaan dan agama. Perselisihan dan perang saudara serta perang antarsuku menjadi pemandangan biasa dalam kehidupan sehari-hari. Pada intinya, saat itu kota Madinah tengah dilanda kekacauan sosial-politik. Dalam konteks demikianlah, Piagam Madinah dibuat dan lahir dari tangan Muhammad SAW yang dibuat berdasarkan kesepakatan bersama. Piagam ini menjadi naskah bersama suku-suku yang ada dalam kota Madinah yang memuat berbagai perjanjian untuk hidup bersama, berdampingan, saling menghormati dan juga saling menjaga. Dengan naskah Piagam Madinah tersebut, realitas sejarah menunjukkan bahwa Muhammad SAW berhasil secara gemilang menyatukan berbagai perbedaan dalam masyarakat Madinah sehingga terbentuklah wawasan kebangsaan dalam keberagaman agama.

Kata Kunci: Dogma dan Politik, Piagam Madinah, Teori Motif dan Teori Maqasid Syariah

\section{A. PENDAhULUAN}

Perkembangan suatu masyarakat tidak terlepas dari sistem norma dalam masyarakat itu, seperti Islam,$^{2}$ Kristen, ${ }^{3}$ ataupun Yahudi, ${ }^{4}$ dari awal

${ }^{2}$ Kepercayaan dasar Islam dapat ditemukan pada dua kalimah shahādatāin ("dua kalimat persaksian"), yaitu "asyhadu an-laa ilaaha illallaah, wa asyhadu anna muhammadan rasuulullaah" - yang berarti "Saya bersaksi bahwa tiada Tuhan selain Allah, dan saya bersaksi bahwa Muhammad saw adalah utusan Allah". Esensinya adalah prinsip keesaan Tuhan dan pengakuan terhadap kenabian Muhammad. Adapun bila seseorang meyakini dan kemudian mengucapkan dua kalimat persaksian ini, ia dapat dianggap telah menjadi seorang muslim dalam status sebagai mualaf (orang yang baru masuk Islam dari kepercayaan lamanya). Kaum Muslim percaya bahwa Allah mengutus Muhammad sebagai Nabi terakhir setelah diutusnya Nabi Isa 6 abad sebelumnya. Agama Islam mempercayai bahwa al-Qur'an dan Sunnah (setiap perkataan dan perbuatan Muhammad) sebagai sumber hukum dan peraturan hidup yang fundamental.

${ }^{3}$ Pemeluk agama Kristen mengimani bahwa Yesus Kristus adalah Tuhan dan Juru Selamat, dan memegang ajaran yang disampaikan Yesus Kristus. Dalam kepercayaan Kristen, Yesus Kristus adalah pendiri jemaat (gereja) dan kepemimpinan gereja yang abadi (Injil Matius 16: 1819)Umat Kristen juga percaya bahwa Yesus Kristus akan datang untuk kedua kalinya sebagai Raja dan Hakim akan dunia ini. Sebagaimana agama Yahudi, mereka menjunjung ajaran moral yang tertulis dalam Sepuluh Perintah Tuhan.Kata Kristen sendiri memiliki arti "pengikut Kristus atau "pengikut Yesus". Murid-murid Yesus Kristus untuk pertama kalinya disebut Kristen.

${ }^{4}$ Yahudi adalah istilah yang merujuk kepada sebuah agama, ras atau suku bangsa. Sebagai agama, istilah ini merujuk kepada umat yang beragama Yahudi. Yahudi diambil menurut salah 
perjalanannya tidak terlepas dari sistem norma dalam instrumen wahyu dan instrumen kerasulan yang didalamnya terdapat prinsip-prinsip ajaran agama, sistem sosial, budaya dan politik yang terimplementasi dalam interaksi sosial yang melekat dalam suatu wilayah, dari sistem sosial inilah maka akan melahirkan sistem prilaku. Dengan demikian perbedaan dogma yang menjadi norma dalam suatu masyarakat akan melahirkan prilaku politik dan sosial yang berbeda-beda.

Berangkat dari pemikiran diatas memunculkan suatu asumsi baru, bahwa perbedaan suatu dogma akan melahirkan perbedaan dalam sistem sosial dan sistem politik seperti yang disaksikan dalam perkembangan sosial dan politik dari berbagai negara. penelitian ini ingin menunjukkan bahwa perbedaan dogma dalam sistem sosial dan sistem politik mampu melahirkan kesatuan dalam praktek politik dalam suatu negara. Hal ini yang mengispirasi penulis untuk mengkaji Piagam Madinah sebagai suatu konstitusi bagi masyarakat yang berbeda-beda dalam dogma, tetapi mampu membangun suatu sistem politik (negara) dalam kesatuan praktek-praktek politik.

Masyarakat Madinah terdiri dari bermacam suku, golongan dan agama. Golongan-golongan itu antara lain para sahabat Rasulullah, kaum musyrikin Madinah, dan kaum Yahudi. Kaum musyrikin madinah adalah kabilah-kabilah asli Madinah. Diantara mereka ada yang masih ragu-ragu meninggalkan agama nenek moyang merekea, namun mereka tidak memusuhi Islam. Sebagaian kaum musyrikin yang lain diam-diam memusuhi Islam. Diantara mereka yang diamdiam memusuhi Islam adalah Abdullah bin Ubay. Ia menampakkan ke-Islaman pada Rasulullah, namun dalam hatinya mereka memusuhi dan merongrong umat Islam. Sebelumnya Abdullah bin Ubay akan diangkat raja di Madinah untuk menyatuhkan suku Aus dan Khazraj. Namun dengan kedatangan Islam, Abdullah bin Ubay batal diangkat menjadi raja. Hal ini yang menyebabkan ia membenci kedatangan Rasulullah dan diam-diam merongrong Islam. ${ }^{5}$

satu marga dari dua belas leluhur Suku Israel yang paling banyak keturunannya, yakni Yehuda. Yehuda ini adalah salah satu dari 12 putera Yakub, seorang nabi yang hidup sekitar abad 18 SM dan bergelar Israil. Seluruh turunan dari 12 putera Yakub (Israel) itu dikenal dengan sebutan Bani Israel (keturunan langsung Israel) yang kemudian berkembang menjadi besar dinamakan menjadi Suku Israel.

${ }^{5}$ H. M. As'ad Bashori, Sejarah Kebudayaan Islam, (Surabaya: Prima Media, 2008), Hlm. 
Selain Abdullah bin Ubay satu orang lagi yang menampakkan permusuhan pada Islam adalah Abu Amir dari suku Aws. Dia sampai bergabung dengan Quraisy Makkah untuk menyerang umat Islam. ${ }^{6}$ Yahudi pun juga pada dasarnya tidak senang akan kedatangan Islam yang berdampak pada hilangnya potensi mereka untuk merebutkan dominasi di Madiah, pada awalnya suku Aws dan Khazrah bersatu untuk menyingkirkan Yahudi dari Madinah namun dengan tipu daya Yahudi dapat memecah bela kedua suku ini untuk perang, sehingga Yahudi dapat legalitas untuk tinggal di Madinah dan mendapatkan keutungan dari perseteruan diantara mereka. ${ }^{7}$ Untuk itu kaum Yahudi menerima kedatangan Islam hanya karena alasan politik yang dengan kedatangan Islam bisa dimanfaatkan untuk kepentingan Yahudi.

Atas dasar itulah demi mewujudkan negara yang kokoh Nabi Muhammad SAW mempersatukan seluruh lapisan golongan masyarakat Madinah dengan diikat oleh Perjanjian yang disebut Piagam Madinah dan diharapkan dapat memperkuat posisi negara Madinah sebagai pusat pemerintahan Islam.

Dimana yang menandatangi Piagam Madinah adalah tokoh kaum Muhajirin dan Anshar, tokoh Yahudi dan Nasrani dari Bani Qainuqa, bani Nadir, dan Bani Quraidah. Mereka menyatakan kesiapan untuk membangun Madinah dan menjaga Madinah dari serangan musuh-musuhnya. ${ }^{8}$ Dari segi itulah, ketertarikan penulis atas signifikasi penelitian ini yang menitik tekankan pada dogma dan politik dalam Piagam Madinah. dimana perbedaan dogma dan politik dalam tatanan negara madinah pada waktu itu menjadi satu kesatuan praktek politik yang di bangun atas perbedaan dogma dan politik yang ada dalam suatu sistem norma dan sistem sosial, sehingga membentuk sistem prilaku yang menjadi satu kesatuan.

\footnotetext{
${ }^{6}$ Martin Lings, Muhammad, (Jakarta: Serambi, 2007), Hlm. 271.

${ }^{7}$ H. M. As'ad Bashori, Sejarah Kebudayaan Islam, (Surabaya: Prima Media, 2008), Hlm.

${ }^{8}$ Budi Sudrajat, Sejarah Kebudayaan Islam, (Jakarta: Yudhistira, 2007), Hlm. 23.
} 19. 


\section{B. PEMBAHASAN}

\section{Struktur Sosial Politik dalam Masyarakat Madinah}

Mengkaji keadaan, peta sosial dan budaya suatu masyarakat adalah penting, karena ia akan menerangkan kepada kita tata cara, pandangan hidup dan organisasi sosialnya yang mempengaruhi pola prilaku kehidupan anggota masyarakat dalam aspek-aspek sosial, ekonomi, politik, hukum, seni, adat-istiadat, tata susila, agama dan keyakinan. Di dalamnya akan ditemukan pola-pola perilaku yang normatif baik cara berpikir maupun cara merasa dan bertindak yang harus dipatuhi oleh seluruh anggota masyarakat. Demikian pula masyarakat Arab sebelum Islam, khususnya di tanah Hijaz, mempunyai struktur sosial dan kultural yang mengatur pola perilaku dan hubungan antarkeluarga maupun antarkelompok masyarakatnya. ${ }^{9}$

Hijaz tempat Muhammad diutus adalah bagian dari Jazirah Arab yang merupakan suatu daerah tandus yang membentang di antara daratan tinggi Nejd dan daerah Pantai Tihamah. ${ }^{10}$ Di sini terdapat tiga kota utama, yaitu Ta'if dan dua kota bersaudara Mekah dan Yasrib ${ }^{11}$ yang kemudian bernama Madinah. Penduduknya terdiri dari bangsa Arab dan bangsa Yahudi. Bangsa Arab tinggal di Mekah, Madinah dan Ta'if, sedangkan bangsa Yahudi tinggal di Madinah dan sekitarnya.

Kedua bangsa ini pada dasarnya merupakan satu ras, yaitu ras Semit ${ }^{12}$. Keduanya berasal dari satu leluhur, yakni Ibrahim melalui dua putranya, Ishaq

\footnotetext{
${ }^{9}$ J. Suyuthi Pulungan, Prinsip-Prinsip Pemerintahan dalam Piagam Madinah Ditinjau dari Pandangan Alquran (Jakarta: RajaGrafindo Persada, 1994), hlm. 25.

${ }^{10}$ Musdah Mulia, Negara Islam; Pemikiran Politik Husain Haikal (Jakarta: Paramadina, 2001), hlm. 177.

${ }^{11}$ Ada yang berpendapat bahwa Yasrib berasal dari bahasa Ibrani atau Aram. Pendapat yang lain menyatakan bahwa nama itu adalah sebutan bagi orang-orang Arab selatan. Ptolemaeus menyebutkan daerah ini bernama Iathrippe. Stephen juga menggunakan kata yang hampir sama dalam kamus geografinya, Iathrippa Polis. Pendapat lain menyebutkan bahwa Yasrib berasal dari nama Yasrib ibn Qaniyah ibn Mihla'Il, orang pertama yang singgah dan menempati kota tersebut. Al-Balazri menyatakan bahwa Yasrib diambil dari nama salah seorang penguasa 'Amaliqah. Lihat, Yasln al-Gadban, Madinah Yasrib qablal-Islam (Jordan: Dar al-Basyir, 1993), hlm. 19 dan Dewan Redaksi Ensiklopedi Islam, Ensiklopedi Islam (Jakarta: Ichtiar Baru Van Hoeve, cet. 9,2011), jilid III, hlm. 101.

${ }^{12}$ Leksikal 'semit' pertama sekali dikenalkan oleh Schlozer dalam penelitiannya Tarikh alUmam al-Gabirah tahun 1781. Dia mengambil salah satu ayat dalam Perjanjian Lama tentang asal-usul bangsa Semit. Dalam simpulannya, Schlozer menyatakan bahwa bangsa Semit berasal dari Sam ibn Nuh. Dari namanya tersebut, terkenal dengan istilah Semit atau al-Samiyah. Lihat, Israel Wolfenson, Tarikh al-Lugat al-Samiyah (Mesir: Matba'ah al-I'timad, 1929), hlm. 2.
} 
dan Isma'H. Bangsa Arab adalah turunan Isma'Tl dan bangsa Yahudi turunan Ishaq. $^{13}$

Selama berabad-abad sebelum Islam, wilayah Hijaz tidak pernah memiliki kesatuan politik di bawah satu bentuk pemerintahan. Hijaz merupakan satusatunya kawasan di Jazirah Arab yang tidak pernah dijarah oleh kekuasaan manapun, termasuk dua kerajaan besar ketika itu, yakni Romawi dan Persia. ${ }^{14}$

Mekah, yang terletak di dalam lembah yang dikelilingi oleh bukit-bukit barisan yang hampir menutupinya, memiliki sejarah panjang sebagai pusat agama atau kota suci dan pusat perdagangan. Sebagai pusat agama, yang ketika itu penyembah berhala, Mekah tempat letaknya $K a^{\prime} b a h$ selalu didatangi oleh berbagai suku dari berbagai penjuru Jazirah Arab sekali dalam setahun pada bulan-bulan suci untuk haji. Kehadiran para pengunjung ini memberikan keuntungan ekonomi bagi penduduk yang mereka peroleh dari pengunjung tersebut. Mekah sebagai pusat perdagangan menjadi kota transit perdagangan Timur-Barat. Jalan keluarmasuk dari dan ke Mekah melalui tiga jalur, yaitu sebelah selatan menuju Yaman, sebelah utara menujuYasrib, Palestina dan Syria dan sebelah barat menuju Laut Merah dan Jeddah. Posisinya ini memberi pengaruh kepada keuntungan ekonomi dan dengan demikian salah satu sumber penghidupan penduduk adalah berdagang. ${ }^{15}$.

Situasi Madinah dalam berbagai aspek kehidupan sangat berbeda dari Mekah. Penduduknya, menjelang hijrah Muhammad ke kota itu terdiri dari bangsa Arab dan bangsa Yahudi yang terbagi ke dalam beberapa suku. Suku-suku terkemuka golongan Arab adalah Aus dan Khazraj yang berimigrasi dari Arabia Selatan, ${ }^{16}$ di samping suku-suku Arab lainnya yang lebih dahulu menetap di kota itu. ${ }^{17}$ Semula daerah ini ditempati oleh suku Amaliqah ${ }^{18}$ yang merupakan salah

${ }^{13}$ Alfred Guillaume, Islam (London: Penguin Books, 1956), h.l 1.

${ }^{14}$ Philip K. Hitti, History ofArabs (London: Macmillan, cet. 10, 1990), hlm. 102.

${ }^{15}$ Suyuthi Pulungan, Prinsip-Prinsip Pemerintahan dalam Piagam Madinah, hlm. 28.

${ }^{16}$ Hitti, History ofArabs, hlm. 104.

${ }^{17}$ Bangsa Arab yang tinggal di Yasrib terdiri dari penduduk setempat dan pendatang dari Arab selatan yang pindah ke Yasrib karena pecahnya Bendungan Ma'rib. Arab pendatang inilah yang terkemuka di kalangan Arab dan dikenal dengan suku Aus dan Khazraj. Lihat, Yasln Gadban, Madinah Yasrib qablal-Islam, hlm. 46 dan Dewan Redaksi Ensiklopedi Islam, Ensiklopedi Islam, hlm. 102.

${ }^{18}$ Menurut Yasln Gadban, secara leksikal, 'Amaliqah berasal dari bahasa Ibrani yang terdiri dari dua kata 'Am dan Maliq. 'Am berarti rakyat dan Maliq merupakan salah satu suku Arab yang berdomisili di sekitar 'Aqabah. Lihat, Yasln Gadban, Madinah Yasrib qablal-Islam, hlm. 47. 
satu komunitas Arab Ba'idah -bangsa Arab yang sudah punah- dan kemudian ditempati suku-suku Arab lain. Secara bertahap daerah itu berkembang menjadi kota terpenting kedua setelah Mekah di tanah Hijaz setelah kehadiran bangsa Yahudi di sana. ${ }^{19}$

Menurut Watt, di Yarib ada delapan suku utama Arab. ${ }^{20}$ Adapun golongan Yahudi mempunyai lebih dari dua puluh suku yang menetap di wilayah itu. Sukusuku yang terkemuka adalah Bani Quraizah, Bani Nadir, Bani Qainuqa', Bani Sa'labah dll. ${ }^{21}$ Mereka ini memiliki kitab suci, lebih terpelajar daripada penduduk Yasrib yang lain dan menguasai perdagangan. ${ }^{22}$

Di Madinah tidak ada pemukiman padat. Dan pemukiman tersebut tersebar di sana-sini di antara semak belukar dan ladang. Setiap kabilah memiliki sejumlah benteng atau kubu tempat mereka berlindung ketika diserang. Sudah menjadi pandangan umum di Madinah bahwa benteng-benteng ini tidak dapat direbut dengan serangan yang hebat. Maka, begitu salah satu pihak dalam suatu peperangan berhasil merebut benteng mereka, pertempuranpun berhenti. ${ }^{23}$

Madinah yang terletak 300 mil atau kurang lebih $485 \mathrm{~km}$ sebelah utara Mekah dan $275 \mathrm{~km}$ dari Laut Merah alamnya lebih menguntungkan dari kota dagang itu. Ia berada di sebuah lembah yang subur. Di sebelah selatan, kota itu berbatasan dengan Bukit 'Ayir; di sebelah utara dengan Bukit Uhud dan ur; dan di sebelah timur dan barat dengan gurun pasir atau Harrah. Bila turun hujan, lembah tersebut menjadi tempat pertemuan aliran-aliran air yang berasal dari selatan dan Harrah sebelah timur. ${ }^{24}$ Di samping terletak di jalan yang menghubungkan Yaman dan Syria, kota itu memiliki sejumlah oase yang dipergunakan untuk penanaman kurma, biji-bijian dan sayur-mayur untuk dimakan. ${ }^{25}$ Karena itu, mayoritas

${ }^{19}$ Ibid.

${ }^{20}$ W. Montgomery Watt, Muhammad Prophet and Statesman (London: Oxford University Press, 1969), hlm. 85.

${ }^{21}$ Suyuthi Pulungan, Prinsip-Prinsip Pemerintahan dalam Piagam Madinah, hlm. 29.

${ }^{22}$ Nucholish Madjid, Islam Agama Peradaban; Membangun Makna dan Relevansi Doktrin Islam dalam Sejarah (Jakarta: Paramadina, cet. 3,2008), hlm. 36.

${ }^{23}$ Watt, Muhammad Prophet and Statesman.

${ }^{24}$ Lihat, Ahmad Sukardja, Piagam Madinah dan Undang-Undang Dasar 1945; Kajian Perbandingan tentang Dasar Hidup Beragama dalam Masyarakat yang Majemuk (Jakarta: TJIPress, 1995), hlm. 20. Lihat juga, Hitti, History of Arabs, Dewan Redaksi Ensiklopedi Islam, Ensiklopedi Islam, hlm. 101, dan Yasln al-Gadban, Madinah Yasrib qablal-Islam, hlm. 24.

${ }^{25}$ Hitti, History of Arabs. 
penduduknya hidup dari bercocok tanam di samping berdagang dan beternak. ${ }^{26}$ Kedudukan kaum Yahudi di kota dipandang sebagai yang paling kuat di kalangan penduduk umumnya. ${ }^{27}$

Hingga awal kedatangan Islam kaum Yahudi masih mendominasi kehidupan ekonomi di Hijaz. Lahan pertanian terbaik dan oase-oase Taima', Fadak dan Wadi al-Qura berada di bawah penguasaan mereka. Kemakmuran kaum Yahudi disebabkan keunggulan pengetahuan di bidang pertanian, irigasi dan industri. Dari segi populasi mereka telah berkembang tidak kurang dari separuh penduduk kota itu. ${ }^{28}$ Menurut Barakat Ahmad, jumlah orang-orang Yahudi yang menetap di Madinah ketika Muhammad tinggal di kota itu diperkirakan sekitar 36 ribu sampai 42 ribu jiwa. ${ }^{29}$ Di samping mereka sebagai pedagang-pedagang kaya yang menguasai pasar, mereka juga tukang-tukang emas dan pembuat senjata serta mempunyai kafilah perdagangan ke Syria sekalipun tidak menyamai skala kafilah perdagangan dari Mekah. ${ }^{30}$

Karena itu, menurut Guillaume, kaum Yahudi merupakan tantangan bagi orang-orang Arab baik Quraisy Mekah maupun Aus dan Khazraj di Madinah. ${ }^{31}$ Sebab kegiatan dagang dan pasar di Madinah yang mereka kuasai di samping memberikan keuntungan ekonomi juga memberikan akses dan pengaruh kepada kekuasaan politik mereka. Oleh karena itu, masalah ekonomi menjadi salah satu faktor timbulnya permusuhan antara kaum Arab dan kaum Yahudi. ${ }^{32}$

Adapun aspek sosial politik antara Mekah dan Madinah terdapat juga perbedaan di samping persamaan. Sejarah menyebutkan bahwa sebelum dan pascalahirnya Islam wilayah Hijaz tidak memiliki pemerintahan dan persatuan politik di bawah satu pemerintahan. Hijaz, memang satu-satunya daerah di Jazirah Arab yang menikmati kemerdekaan sejak lama tanpa dipengaruhi oleh pergolakan politik yang diperankan oleh sejumlah kerajaan Arab; Arabia Utara dan Selatan

\footnotetext{
${ }^{26}$ Dewan Redaksi Ensiklopedi Islam, Ensiklopedi Islam, hlm. 101-102.

${ }^{27}$ Suyuthi Pulungan, Prinsip-Prinsip Pemerintahan dalam Piagam Madinah, hlm. 31.

${ }^{28}$ Guillaume, Islam, hlm. 12.

${ }^{29}$ Barakat Ahmad, Muhammad and the Jews (New Delhi: Vikas Publishing House PVT

${ }^{30}$ Watt, Muhammad Prophet and Statesman, hlm. 84 dan Badri Yatim, Sejarah Peradaban Islam; Dirasah Islamiyah II (Jakarta: RajaGrafindo Persada, 2008), hlm. 15.

${ }^{31}$ Guillaume, Islam.

${ }^{32}$ Suyuthi Pulungan, Prinsip-Prinsip Pemerintahan dalam Piagam Madinah, hlm. 33.
} LTD, 1979), hlm. 43. 
maupun Kerajaan Romawi dan Persia. ${ }^{33}$ Perbedaannya, jika Mekah diperintah oleh aristokrat Quraisy, maka di Madinah tidak terdapat persatuan dan kesatuan penduduk di bawah satu pemerintahan. Situasi yang tidak baik ini berasal dari konflik yang terus-menerus antara dua suku, Aus dan Khazraj yang sama-sama berasal dari Arabia Selatan. Situasi semakin manjadi rumit dengan kehadiran suku-suku Yahudi yang melibatkan diri dalam konflik itu. ${ }^{34}$

Pemerintahan di Mekah ketika dijabat oleh Qusay ibn Kilab semakin baik dan terstruktur. Ini terbukti dengan disusunnya dewan pemerintahan untuk mengatur dan melayani rakyat dan pemerintah. Dewan ini terdiri dari hijabah, liwa, siqayah dan rifadah serta nadwah. Hijabah adalah penjaga dan pemegang kunci Kabah. Liwa' adalah petugas pembawa panji dalam peperangan. Siqayah dan rifadah adalah petugas-petugas yang menyediakan makanan bagi jemaah haji. Nadwah adalah lembaga musyawarah. Semua lembaga ini dipegang oleh keturunan Quraisy, seperti Abd al-Mutallib, kakek Muhammad hingga datangnya Islam. ${ }^{35}$ Di samping itu, Syed Amir Ali menambah lima dewan lagi dalam struktur pemerintahan Qusay, yaitu diyah, sifarah, khaimmah, khazinah dan azlam. Diyah adalah kekuasan hakim sipil dan kriminal. Sifarah adalah kuasa usaha negara atau duta. Khaimmah adalah pengurus balai musyarawah. Khazinah adalah jabatan administrasi keuangan. Azlam adalah penjaga panah peramal untuk mengetahui pendapat dewa-dewa. ${ }^{36}$

Walaupun kota Mekah mempunyai pemerintahan yang relatif lebih teratur daripada Madinah, namun konflik antar suku tetap saja terjadi. Konflik bersumber pada pola struktur masyarakat Arab yang didasarkan pada organisasi klan, yang mengikat semua anggota keluarga di dalam suku yang disebut dengan pertalian darah. ${ }^{37}$ Pertalian darah ini menimbulkan rasa solidaritas yang kuat di antara suku yang melahirkan sikap loyalitas penuh terhadap kesatuan suku. Sikap ini membawa kepada timbulnya kap fanatisme kelompok yang berlebihan, yang dalam istilah .rab disebut 'asabiyyah. ${ }^{38}$

\footnotetext{
${ }^{33}$ Hitti, History ofArabs, hlm. 102.

${ }^{34}$ Suyuthi Pulungan, Prinsip-Prinsip Pemerintahan dalam Piagam Madinah, hlm. 38.

${ }^{35}$ Hasan Ibrahim, Tarikh al-Islam, hlm. 45-47.

${ }^{36}$ Syed Amir Ali, Api Islam (Jakarta: Bulan Bintang, 1978), hlm. 97-99.

${ }^{37}$ Ibid.,h. 39.

${ }^{38}$ Ahmad Amin, Fajr al-Islam (Kairo: Maktabah al-Nahdah al-Misriyyah, 1979), hlm. 10.
} 
Semangat ini dapat menimbulkan chauvinisme yang lendalam, yaitu sikap yang menganggap suku lain sebagai lusuh yang harus dibinasakan. Setiap suku yakin mampu erdiri sendiri tanpa hidup berdampingan dengan suku-suku un, sehingga hampir tidak ada hubungan harmonis dan akrab ntara satu suku dengan lainnya. Karena itu, setiap anggota uku mempunyai kewajiban membela anggota lain yang berada lalam keadaan bahaya, sekalipun ia sesungguhnya bersalah. Dalam arti, ia harus dibela apakah ia menganiaya atau dianiaya uiggota suku lain. Sebagai contoh, seseorang membunuh mggota suku lain, maka setiap anggota suku dari si pembunuh larus membelanya karena klan si terbunuh akan menuntut balas pembunuhan terhadap si pembunuh. Sebab, suatu pembunuhan harus diselesaikan atau dibalas dengan pembunuhan pula atau bayar denda. ${ }^{39}$ Dendam pembunuhan itu bisa berlangsung selama 40 tahun yang mengakibatkan sering terjadi permusuhan atau peperangan antarsuku. ${ }^{40}$ Peperangan yang termasyhur di kalangan Arab Jahiliyyah ${ }^{41}$ adalah perang Busus antara suku Bakr dan Taglib di Timur Laut Arabia. Perang Dahis dan al-Gubra' antara dua pimpinan suku ini di Arabia Tengah, masing-masing berlangsung selama 40 tahun karena masalah kecil. Perang Fijar, yaitu perang antara suku-suku di Hijaz yang berlangsung selama 4 tahun. Peperangan antara suku ini dikenal dengan istilah ayyam al'Arab. ${ }^{42}$

Namun, menurut Ibn Khaldun, 'asabiyyah ${ }^{43}$ di kalangan bangsa Arab justru mengandung konotasi positif, yaitu rasa persatuan, kerja sama dan tolong-

39 Ibid.

${ }^{40}$ Suyuthi Pulungan, Prinsip-Prinsip Pemerintahan dalam Piagam Madinah, hlm. 40.

${ }^{41}$ Ibn Manzur mengartikan jahiliyyah dengan kondisi Arab pra-Islam yang tidak mengenal Allah, Rasul-Nya dan syiar agama. Namun, lebih suka membanggakan nasab atau keturunan dan arogansi. Lihat, Abu al-Fadl Jamal al-DIn Muhammad bin Mukram ibn Manzur, Lisan al-'Arab (Beirut: Dar al-Sadir, 1992), jilid XI, hlm. 130. Menurut 'Abd al-Syaft jahiliyyah merupakan suatu gambaran bagi kaum yang sesat dari jalan yang benar; mereka keras kepala dan arogan, permusuhan sengit dan sangat fanatik terhadap sukunya. Lihat, 'Abd al-Syafl Muhammad 'Abd alLatif, Tarikh al-Islam fi 'asr al-Nubuwwah (Kairo: Al-Ma'had al-'AH lid-Dirasat al-Islamiyyah, 2005), hlm. 24. Menurut Hitti, jahiliyyah adalah periode pada waktu di Jazirah Arab tidak berlaku petunjuk Tuhan, tidak ada nabi dan tidak mempunyai kitab. Maksud penggunaan istilah ini untuk menghentikan orang Arab dari ikatan ide-ide keagamaan pra-Islam, terutama pemujaan terhadap berhala. Lihat, Hitti, History ofthe Arabs, h, 87.

${ }^{42}$ Hasan Ibrahim, Tarikh al-Islam, hlm. 57-61.

${ }^{43}$ Secara epistemologis, 'asabiyyah berasal dari kata kerja 'asaba yang berarti sendi-sendi yang terikat erat satu sama lain. Ibn Manzur menvisualisasikan 'asabiyyah sebagai seorang lelaki yang mengajak para pengikutnya untuk berkumpul dan bersepakat melakukan perlawanan terhadap siapa saja yang menentang mereka, baik mereka menganiaya ataupun teraniaya. Lihat, Ibn Manzur, Lisan al- 'Arab, jilid I, hlm. 602 dan 606. S. Pulungan mengartikan 'asabiyyah dengan 
menolong yang sangat kuat dalam suatu kelompok sehingga setiap anggota dalam kelompok tersebut bersedia mengorbankan jiwa raganya demi kepentingan kelompok dan seluruh anggotanya. Karena itu, dalam mendirikan sebuah negara peranan 'asabiyyah sangat menentukan. ${ }^{44}$ Dengan demikian, 'asabiyyah yang dimiliki oleh bangsa Arab memiliki dua sisi: dapat membawa kepada konflik sekaligus persatuan, sebagai salah satu unsur yang diperlukan dalam pembentukan sebuah negara. ${ }^{45}$

'Asabiyyah ini timbul karena faktor-faktor pertalian darah atau pertalian kaum dan rasa cinta seseorang terhadap nasab dan golongannya. Hal ini akan menimbulkan perasaan senasib dan sepenanggungan serta melahirkan kerja sama dalam berbagai bidang. 'Asabiyyah juga melahirkan persatuan dan pergaulan di antara mereka. Dengan 'asabiyyah ini penguasa akan memilih orang-orang yang memiliki hubungan dengan penguasa ke dalam jajaran pemerintahannya. ${ }^{46}$

Lain halnya kehidupan masyarakat di Yasrib. Kehidupan di kota ini dapat dikatakan lebih tidak teratur, karena penduduknya yang heterogen itu tidak berhasil mewujudkan persatuan dan kesatuan yang berada di bawah satu pemerintahan dan membawahi semua kabilah. Dilihat dari segi sosio-politik masyarakat yang bercorak demikian menyimpan potensi untuk timbulnya konflik antara kelompok. ${ }^{47}$ Di Yairib tidak ada seorang pemimpin dan suatu pemerintahan atas nama penduduk; yang ada adalah pemimpim-pemimpin suku yang selalu memikirkan kepentingan suku masing-masing. Mereka saling bersaing atau berperang untuk menanamkan pengaruh di masyarakat. Akibatnya di antara sukusuku yang ada itu sering terjadi permusuhan, bahkan peperangan. ${ }^{48}$

\footnotetext{
'perasaan satu kelompok' atau 'kesatuan kelompok' dan atau 'solidaritas sosial'. Lihat, S. Pulungan Prinsip-Prinsip Pemerintahan dalam Piagam Madinah, hlm. 39. Musdah mengartikannya dengan 'solidaritas kelompok'. Lihat, Musdah, Negara Islam, hlm. 179. Senada dengan Musdah, M. Iqbal mengartikannya dengan 'solidaritas kelompok'. Lihat, M. Iqbal dan Amin Husein Nasution, Pemikiran Politik Islam dari Masa Klasik hingga Indonesia Kontemporer (Jakarta: Kencana, 2010), hlm. 50. Selain itu, 'asabiyyah juga dapat dipahamai sebagai solidaritas sosial, dengan menekankan pada kesadaran, kepaduan dan persatuan kelompok. Lihat, Jhon L. Esposito (ed)., Ensiklopedi Dunia Islam Modern (Bandung: Mizan, 2001), jilid I, hlm. 198.

${ }^{44}$ Ibn Khaldun, Muqaddimah, (t.t.p.: Dar al-Fikri, t.t.), hlm. 128-130.

${ }^{45}$ Musdah, Negara Islam.

${ }^{46}$ M. Iqbal dan Amin Husein Nasution, Pemikiran Politik Islam, hlm. 50-51.

${ }^{47}$ Suyuthi Pulungan, Prinsip-Prinsip Pemerintahan dalam Piagam Madinah, hlm. 44.

${ }^{48}$ Dewan Redaksi Ensiklopedi Islam, Ensiklopedi Islam, hlm. 102.
} 
Menurut David E. Apter, kelompok-kelompok masyarakat yang berkonflik justru semakin memperkokoh kekuasaan dan kesatuan setiap kelompok. Bila suatu saat, satu kelompok bersekutu dengan kelompok lain, kemudiaan di saat yang lain bersekutu pula dengan kelompok lain lagi, sangat tergantung kepada situasi dan keuntungan yang diperoleh dari persekutuan itu. Sikap yang demikian semakin mempertajam konflik. ${ }^{49}$

Dalam teori ilmu politik, suatu komunitas yang terdiri dari berbagai kelompok etnis, tingkat ekonomi, agama dan keyakinan serta adat istiadat mempunyai perbedaan kepentingan yang menyolok. Perbedaan itu terlihat dalam berbagai bidang kehidupan mereka, seperti bidang sosial, ekonomi dan politik sehingga mereka cenderung untuk saling bermusuhan. ${ }^{50}$ Karena di dalam diri manusia, sebagai makhluk sosial dan makhluk politik, terdapat dua sifat yang saling bertentangan; di satu segi, ia ingin bekerja sama dengan sesamanya, namun di segi lain, ingin berkompetisi. ${ }^{51}$

Demikianlah yang terjadi di Madinah, yaitu konflik antara dua suku utama Arab, Aus dan Khazraj di satu pihak dan konflik di antara kedua kelompok itu dengan suku-suku Yahudi di lain pihak. Mereka bersaing merebut pengaruh atas masyarakat Madinah untuk menjadi penguasa di kota itu. Sehingga tercatat ada dua belas kali peperangan yang terjadi antara Aus dan Khazraj. ${ }^{52}$ Namun kedua suku ini pernah bersatu menyerang orang-orang Yahudi. Dalam serangan itu orang-orang Yahudi banyak terbunuh dan kedudukan mereka sebagai yang dipertuankan berhasil dijatuhkan. Peristiwa tersebut mempertajam permusuhan dan kebencian kaum Yahudi terhadap kaum Arab, demikian pula sebaliknya. ${ }^{53}$

Belajar dari pengalaman itu, kaum Yahudi melihat bahwa melawan kaum Arab dengan kekerasan kurang menguntungkan. Karena itu, mereka melakukan siasat memecah belah dengan melakukan intrik, menyebarkan provokasi permusuhan dan kebencian di tubuh Aus dan Khazraj agar mereka saling

49 David E. Apter, The Politics of Modernization (Chicago: The University of Chicago Press, 1969), hlm. 98.

${ }^{50}$ Soerjono Soekanto, Sosiologi Suatu Pengantar (Jakarta: Rajawali, 1982), hlm. 94.

${ }^{51}$ Musdah, Negara Islam, hlm. 183.

${ }^{52}$ Kedua belas peperangan tersebut adalah Samir, Surrah, al-Husain ibn al-Aslat, Rabi' alZufri, F ari', Hatib, Rabi', BaqT', Fijar, Ma'bas wa Midras, Fijar II dan terakhir Bu 'as. Lihat Mustafa Kamal Wasfi, Muhammad wa Banu Isra 'U (Kairo: Lajnah al-Khubara', 1967), hlm. 23.

${ }^{53}$ Suyuthi Pulungan, Prinsip-Prinsip Pemerintahan dalam Piagam Madinah, hlm. 44-45. 
bermusuhan sehingga mereka tidak dapat bersatu dan kekuatan mereka menjadi lemah. Siasat ini berhasil dengan baik dan mereka merebut kembali posisi semula terutama di bidang ekonomi. ${ }^{54} \mathrm{Di}$ samping menimbulkan permusuhan di antara kedua suku itu, juga menghasilkan persekutuan dengan kaum Yahudi. Kelompok Khazraj bersekutu dengan Bani Qainuqa, sedangkan kelompok Aus bersekutu dengan Bani Quraizah dan Bani Nadir. ${ }^{55}$ Persekutuan ini justru melemahkan kekuatan dan kekuasaan dua suku Arab itu dan Yahudi selalu mencegahnya agar keduanya tidak mengkonsolidasikan kekuasaannya. ${ }^{56}$

Politik adu domba ini mencapai klimaks permusuhan dua kelompok Arab itu, yaitu timbulnya peperangan dahsyat antara mereka sekitar tahun $618 \mathrm{M}$ di suatu tempat yang bernama Bu'as dan kemudian terkenal dengan perang Bu'as. Menurut Watt, sebagian besar kabilah Arab Madinah terlibat dalam pertempuran ini, dan juga sebagian sekutu mereka, kabilah-kabilah Yahudi dan beberapa suku badui tetangga mereka. Terjadi pembantaian besar-besaran. Peperangan berhenti hanya karena kedua belah pihak sudah kehabisan tenaga, namun belum tercapai perdamaian. ${ }^{57}$

Dalam perang itu pihak Aus menderita kekalahan. Tapi kemudian mereka membalas dendam dengan menyerang Khazraj habis-habisan, membakar rumahrumah dan kebun kurma mereka. Sementara Abu Usaid Hudair, pemuka Aus, berniat mendatangi rumah-rumah Khazraj untuk menghabisi mereka. Niat ini dicegah oleh Abu Qais ibn al-Aslat dan berkata: "Bertetangga dengan mereka lebih baik daripada bertetangga dengan Yahudi." ${ }^{58}$ Begitu selesai perang, baik Aus maupun Khazraj segera menyadari akibat permusuhan mereka, sehingga mereka berdamai dan sepakat mengangkat Abdullah ibn Muhammad, orang Khazraj yang berperangai baik, untuk menjadi pemimpin mereka. Tetapi rencana ini tidak terlaksana, karena beberapa orang Khazraj pergi ke Mekah pada musim haji. ${ }^{59}$

${ }^{54}$ Haikal, Hayatu Muhammad, hlm. 21.

55 'AH Husni al-Khurbutuli, Al-Rasul fd-Madinah (Mesir: Lajnah al-Ta'rif bil-Islam.t.t.), hlm. 15-16.

${ }^{56}$ Wasfi, Muhammad wa Banu Isra'il.

${ }^{57}$ Watt, Muhammad Prophet and Statesman, hlm. 87.

${ }^{58}$ Haikal, Hayatu Muhammad, hlm. 214.

${ }^{59}$ Ibid. 
Dalam uraian di atas, tampak bahwa corak kehidupan masyarakat yang tinggal menetap di kota-kota, seperti Mekah dan Madinah tidak berbeda dari corak kehidupan masyarakat yang hidup secara nomaden. Dalam pola hidup nomaden, masyarakatnya hanya mengenal kebebasan pribadi, kebebasan keluarga dan kebebasan kabilah tanpa terikat pada aturan dan norma sosial. Pola hidup ini terjadi pula di kalangan masyarakat Mekah dan Madinah. Demikian pula susunan suku, perangai hidup, adat istiadat dan ketidaksukannya terhadap segala sesuatu yang membatasi kebebasan sehingga lebih dekat kepada pola kehidupan nomaden daripada pola hidup di kota. Sekalipun mereka hidup menetap di kota, tapi tidak mencerminkan pola hidup kota, yaitu demi untuk tata tertib, masyarakatnya mau mengalah dan meninggalkan sebagian kemerdekaannya untuk kepentingan masyarakat umum dan penguasa sebagai imbalan atas keamanan dan kemewahan yang mereka peroleh. ${ }^{60}$ Kondisi ini tidak tercermin dalam kehidupan masyarakat Mekah sekalipun mempunyai pemerintahan, terlebih-lebih Madinah, karena kota yang penduduknya heterogen itu tidak memiliki pemerintahan yang mengintegrasikan semua kelompok sosial. Setiap kelompok sosial hidup dengan caranya sendiri dan memikirkan kepentingan kelompoknya sendiri. ${ }^{61}$

\section{Proses Pembangunan Kesatuan dalam Masyarakat Madinah}

Muhammad Rasulullah untuk pertama kali mendapat pengakuan sebagai pemimpin dan kelompok penduduk Madinah pada Baiat 'Aqabat Pertama (621 M) dan Baiat 'Aqaba/ Kedua (622 M). Dalam ikrar baiat itu, selain pengakuan tersebut dan keimanan kepada beliau sebagai Rasul Allah serta penerimaan Islam sebagai. agama mereka, terdapat juga pernyataan kesetiaan, ketaatan, dan penyerahan kekuasaan kepada beliau. Posisinya ini kemudian menjadi ku at setelah di Madinah. Ini tampak dalam langkah beliau yang mampu mengendalikan orang-orang Islam Muhajirin dan Ansar secara nyata dan efektif dengan mempersaudarakan mereka. Langkah inilah yang membawa kepada terbentuknya komunitas Islam untuk pertama kali. Dilihat dari sudut teori politik, ini menunjukkan bahwa beliau memiliki "kekuasaan sosial" di kalangan pengikutnya. Kekuasaan sosial adalah "kemampuan mengendalikan tingkah laku orang lain

\footnotetext{
${ }^{60}$ Ibid., hlm. 14-16.

${ }^{61}$ Suyuthi Pulungan, Prinsip-Prinsip Pemerintahan dalam Piagam Madinah, hlm. 47.
} 
baik secara langsung dengan memberi perintah maupun secara tidak langsung dengan memanfaatkan segala alat dan cara yang tersedia". ${ }^{62}$

Dalam perkembangan berikutnya, pada tahun pertama hijrah beliau memperoleh pengakuan yang lebih luas di luar interen umat Islam, yaitu dari suku-suku Yahudi dan sekutunya di wilayah Madinah. Ini ditandai dengan lahirnya perjanjian tertulis (Piagam Madinah) antara orang-orang muslim Muhajirin bersama Ansar dan kaum Yahudi bersama sekutunya yang diprakarsai oleh Nabi. Dalam perjanjian tertulis itu, Nabi diakui sebagai pemimpin tertinggi dan sebagai hakam bagi penandatangan Piagam serta siapa saja yang bergabung dengan mereka.

Dengan adanya pengakuan itu, berarti kekuatan dan kekuasaan politik ${ }^{63}$ benar-benar telah dimiliki oleh Nabi. Ini berarti beliau juga telah memperoleh keabsahan (legitimasi) sebagai pemimpin masyarakat Madinah.

Walaupun dalam Baiat 'Aqaba/ hanya hadir sekelompok orang-orang Arab Madinah, danperjanjian tertulis mungkin hanya diikuti oleh beberapa orang pemimpin atau pemuka setiap suku dan kalangan orang-orang muslim dan nonmuslim yang mewakili warga sukunya, namun dapat dikatakan bahwa mereka telah membawa aspirasi segenap penduduk Madinah, yang dalam istilah teknisnya disebut "kehendak rakyat". Setiap suku yang ada di Madinah waktu itu tercantum dalam teks Piagam. Dalam praktek politik, "kehendak rakyat" jarang sekali — itupun jika pemah ada, merupakan kehendak seluruh rakyat. Dalam negara dem olcrasi terang tidak ada, dan mungkin juga tidak dalam negara berbcntuk apapun, pemerintah yang sedang berkuasa merupakan pilihan semua warga negara. ${ }^{64}$ Artinya, walaupun seluruh rakyat tidak terlibat secara langsung dalam proses pemilihan pemerintah yang berkuasa sexing diklaim sebagai "kehendak rakyat."

Demikian juga halnya pelalcsanaan "kontrak sosial" (perjanjian masyarakat). Peserta-pesertanya, sebenamya, bukan seluruh anggota masyarakat

${ }^{62}$ Lihat Maclver, op. cit., hlm. 87.

63 "Kekuasaan politik adalah "kemampuan untuk mempengaruhi kebijaksanaan umum (pemerintah) baik terbentuknya maupun akibat-akibatnya sesuai dengan tujuan-tujuan pemegang kekuasaan sendiri." Kekuasaan itu disarnping untuk memperoleh ketaatan dan warga masyarakat juga menyangkut pengendaBan orang lain dengan tujuan untuk mempengaruhi tindakan aktivitas negara di bidang administratif, legislatif, dan yudikatif. Lihat Budiardjo, op. cit., him. 37.

${ }^{64}$ MacIver, The Modern State, op. cit., hlm. 14. 
yang menetap di suatu wilayah, tapi hanya antara individu-individu dari dua belah pihak yang saling berhadapan, yaitu antara anggota-anggota masyarakat yang sudah terbentuk dan seorang atau sekelompok orang dari kelompok sosial ${ }^{65}$.

Thomas Hobbes juga berpendapat bahwa perjanjian masyarakat diadakan oleh individu-individu untuk membentuk suatu masyarakat politik atau negara. ${ }^{66}$ Kesepalcatan yang diperoleh melalui perjanjian masyarakat, menurut John Locke, sekalipun itu kesepakatan individu-individu dapat dianggap sebagai tindakan seluruh warga masyarakat, dan karenanya mewajibkan individu-individu lain mentaati persetujuan tersebut. ${ }^{67}$ Teori ini tampaknya sejalan dengan konsep 'ashabiyyaLnya Ibn Klialdan sekalipun ia tidak berbicara dalam konteks kontrak sosial. $^{68}$

Berdasarkan teori-teori tersebut, maka baik peristiwa Baiat 'Aqabat yang diikuti oleh sekelompok orang Arab Madinah maupun terwujudnya perjanjian tertulis yang pesertanya mungkin hanya wakil-wakil dari kelompok-kelompok sosial (suku-suku), dapat disebut sebagai "kontrak social." Kontrak sosial adalah suatu teori yang mengajarkan bahwa kekuasaan politik diperoleh melalui perjanjian masyarakat. Artinya, kekuasaan politik bersumber dari rakyat dan legitimasinya diperoleh melalui perjanjian masyarakat. Dengan kata lain bahwa dalam perjanjian masyarakat itu terjadi penyerahan kekuasaan oleh anggota masyarakat kepada seseorang atau kepada lembaga. ${ }^{69}$

Perjanjian masyarakat merupakan salah satu teori tentang asal mula terbentuknya negara yang bersifat universal, karena ia terdapat baik dalam

${ }^{65}$ F Isjwara, Pengantar Ilmu Politik, Bina Cipta, Bandung, 1980, hlrn. 140.

66 Lihat ibid., hlm. 145.

67 Lihat ibid., hlm. 146.

${ }^{68}$ Ibn Khaldiln berpendapat bahwa suatu 'ashabiyyat (solidaritas sosial) yang kuat akan menguasai 'ashabiyyat-'ashabiyyat lain yang tidak kuat dengan membuat perjanjian dan runduk kepadanya, sehingga menjadi suatu koalisi bagaikan 'ashabiyyat yang besar. Karena jika satu 'ashabiyyat telah memperoleh superioritas atas rakyat golongannya, maka ia akan mengendalikan rakyat 'ashabiyyat-' ashabiyyat lain yang tidak ada hubungan apa-apa dengannya untuk bergabung dengan ashabiyyat-nya atas dasar perjanjian. Lihat Ibn Khaldim, op. cit., him. 139-140. Hal ini tarnpak dalarn tindakan Nabi, setelah masyarakatIslam menjadi kuat solidaritas sosialnya ('ashabiyyat) di Madinah, beliau menarik suku-suku lain untuk bergabung dengannya atas dasar perjanjian.

${ }^{69}$ Deliar Noer, Pemikiran Politik di Barat, Rajawali, Jakarta, 1982, hlm. 79 
masyarakat Barat maupun dalam masyarakat Timur, baik dalam agama Nasrani maupun dalam agama Islam. ${ }^{70}$

Dalam sejarah Islam peristiwa Baiat 'Aqabat clan perjanjian tertulis yang melahirkan Piagam Madinah, sebagai telah disebut, dapat diidentifikasikan sebagai praktek kontrak sosial. Karena dalam peristiwa-peristiwa itulah Nabi memperolch kekuasaan politik dan keabsahan untuk mengatur dan memimpin penduduk Madinah. Menurut Fazlur Rahman, suatu negara atau pemerintahan dapat dibentuk apabila sekelompok orang menyatakan kesediaan melaksanakan kehendak dari Allah sebagai yang tercanturn dalam wahyu-Nya. ${ }^{71}$ Pandangan ini sejalan dengan teori kontrak sosial tersebut, bahwa suatu negara terbentuk apabila terjadi perjanjian masyarakat sekalipun peserta-pesertanya sekelompok orang dari pihak-pihak yang mengadakan perjanjian tersebut.

Dengan demikian, kekuasaan politik yang diperoleh Nabi berdasarkan nash dan fakta-fakta his toris tersebut, bukan menurut teori kekuatan, ${ }^{72}$ karena kehadirannya di Madinah bukan dengan jalan kekuatan dan penaklukan melainkan karena diundang oleh golongan-golongan Arab di kota itu dan atas perintah wahyu. Hak dan kekuasaan politik itu beliau peroleh dari Allah yang dalam ilmu politik disebut teori teokratis, ${ }^{73}$ juga beliau peroleh melalui perjanjian masyarakat yang disebut teori kontrak sosial.

Perjanjian masyarakat yang terjadi antara Nabi dan komunitas-komunitas penduduk Madinah membawa mereka kepada kehidupan social yang teratur dan terorganisir, atau dari "zaman pra-negara ke zaman bemegara" di bawah kepemimpinan Nabi Muhammad SAW. Dikatakan demikian, karena seperti telah disinggung di muka bahwa mereka tidak mempunyai pemerintahan dan pemimpin yang dapat rnempersatukan mereka dalam kehidupan yang teratur dan terorganisir. Keadaan tak bemegara (pra-negara) yang disebut keadaan alamiah

${ }^{70}$ Isjwara, op. cit., hlm. 136.

${ }^{71}$ FazIur Rahman, "The Islamic Concept of State", dalam John J. Donohue and L. Esposito, (eds.), Islam inTransition, Muslim Perspective, Oxford University Press, New York, 1982, hlm. 126

72 Kekuasaan politik atau negara terbentuk dengan jalan penaklukan dan pendudukan oleh suatu kelompok terhadap kelompok Maka negara dibentuk oleh kelompok yang menang dan kckuatanlah yang membentuk kekuasaan dan membuat hukum. Lihat Isjwara, op. cit., him. 153.

${ }^{73}$ Menurut teori teokratis, kekuasaan berasal dari Tuhan, yakni penguasa bertahta atas kehendak Tuhan untuk memerintah. Isjwara, op. cit., hlm. 152 dan Krenenburg dan TK Sabaruddin, Ilmu Negara, Pradnya Paramita, Jakarta, 1986, hlm. 9. 
(state of nature, status naturalis) adalah masyarakat yang tanpa organisasi pemerintahan yang mengatur mereka. ${ }^{74}$ Keadaan hidup alamiah ini menyerupai keadaan di laut di mana "ikan besar makan ikan kecil" atau menurut Hobbes keadaan "perang antara semua lawan semua." 75 Keadaan seperti inilah yang terjadi antara suku-suku Arab dan Yahudi yang tinggal di Madinah sebelum Nabi hijrah ke sana.

Adapun peralihan dari zaman pra-negara ke zaman bemegara ditandai dengan terlaksananya suatu perjanjian oleh semua golongan untuk hidup bersama di suatu wilayah tertentu pada waktu tertentu. ${ }^{76}$ Situasi seperti ini telah berhasil diwujudkan oleh Nabi bersama semua golongan di Madinah. Artinya terlaksananya perjanjian tertulis yang dibuat Nabi dan disetujui oleh semua golongan adalah suatu indikator atau pemyataan terbentuknya negara dan pemerintahan di bawah pimpinan Nabi Muhammad di Madinah.

\section{Pijakan Nilai dalam Pembangunan Kesatuan Dogma dan Politik dalam Piagam Madinah}

Nilai-nilai yang manjadi pijakan dalam pembangunan politik yang ada dalam Piagam Madinah yang paling mendasar, ialah: (1) Hak atas kebebasan beragama; (2) Hak atas persamaan di depan hukum; (3) Hak untuk hidup; dan (4) Hak memperoleh keadilan. ${ }^{77}$

\section{a. Pembangunan Nilai Melalui Teori Sistem Dogma dan Politik}

Proses pembangunan nilai melalui teori dogma dan politik yang penulis gagas ini adalah karena adanya asumsi baru bahwa perbedaan suatu dogma akan melahirkan perbedaan sistem sosial dan sistem politik, maka akan melahirkan sistem prilaku yang berbeda.

Melalui penelitian ini penulis akan menunjukkan bahwa perbedaaan dogma dan politik dalam masyarakat madinah untuk mencapai kesepakatan Piagam Madinah sebagai aturan dalam pemerintahan dengan proses pembangunan kesatuan Ummah yang telah disebut dalam Piagam Madinah untuk dimasudkan

${ }^{74}$ Lihat Isjwara, op. cit., hlm. 139.

75 'Lihat ibid., hlm. 138.

${ }^{76}$ Lihat ibid., hlm. 140.

77 Naskah Piagam Madinah dimaksud ialah yang didokumentasikan dalam Ibn Hisyâm, Sîrah al-Nabiy, (t.tp.: Dar al-Fikr, 1981), Juz ke-2, hlm. 119. 
bagi seluruh masyarakat yang meyepakati aturan tersebut, dengan tidak melihat etnisitas, agama, status sosial ataupun golongan tertentu, kecuali kepada orangorang yang berkhianat (Dhalim) akan diberi hukuman sesuai dengan kesepakatan dalam Piagam Madinah. maka dari sinilah terbentuknya konsep pembangunan wawasan kebangsaan dalam Piagam Madinah. hal ini penulis telah mengambarkan kerangka kerja teori dogma dan politik yang penulis gagas pada gambar 1.

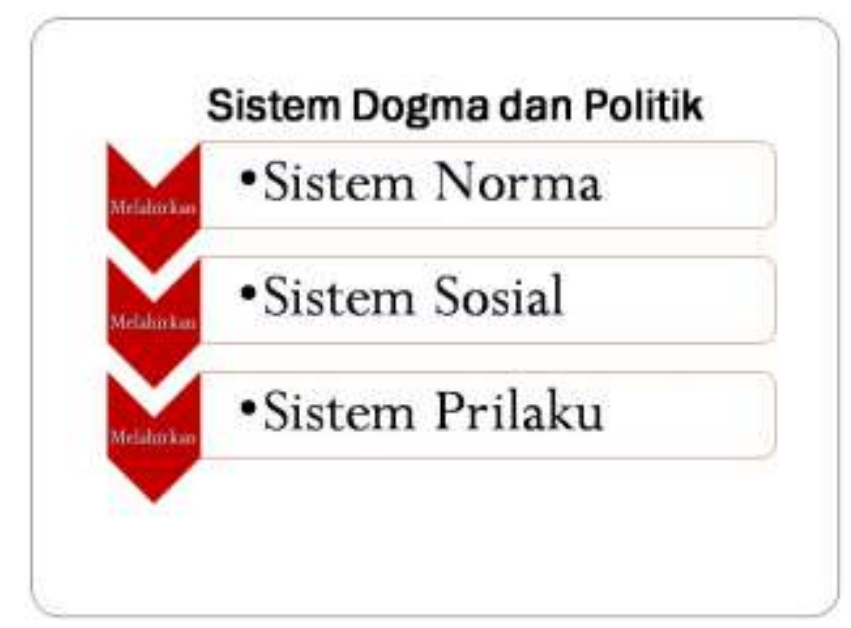

(Gambar 1) Kerangka Kerja Teori Sistem Dogma dan Politik

\section{b. Pembangunan Nilai Melalui Teori Motif}

Proses pembangunan nilai melalui teori motif dalam Piagam Madinah adalah Dogma yang menjadi nilai-nilai dalam sistem norma dan sosial sehingga membentuk sistem prilaku. Sosial (Lingkungan dan Masyarakat) di Madinah, kemudian Konstruk Pemikiran (Muhammad SAW), Idealisme (Prinsip), Masa Depan Masyarakat (kesatuan umat), Tujuan (satu titik tujuan masyarakat), Pencapaian (Piagam Madinah), maka dari situlah munculnya Prilaku yang seirama dengan Konstruk Pemikiran yang telah dibawakan oleh Muhammad SAW. hal ini telah penulis gambarkan pada kerangka kerja teori motif pada gambar 2. 




(Gambar 2) Kerangka Kerja Teori Motif

Maka dari sinilah dapat mengetahui Nilai-nilai yang menjadi pijakan masyarakat dalam pembentukan Piagam Madinah menjadi suatu konstitusi dalam masyarakat Madinah yang dibawakan oleh Muhammad SAW adalah Nilai Humanism (kemanusiaan), Equality (persamaan) dan Justice (keadilan). Sehingga konstruk pemikiran berjalan seirama dengan menghasilkan prilaku kesatuan praktek politik dalam masyarakat dan lingkungan yang diharapkan.

\section{c. Pembangunan Nilai Melalui Teori Maqasid Syariah}

Menurut Penulis, Relevansi Teori Maqashid Syariah pada proses pembangunan nilai dalam Piagam Madinah adalah :

1. Prinsip memelihara agama merupakan salah satu prinsip Maqasid Syariah yang mempunyai relevansi dengan perlindungan hak asasi manusia, yakni hak atas kebebasan beragama. Prinsip ini melandasi ketentuan bahwa setiap orang bebas memeluk agamanya masing-masing dan untuk beribadat menurut agamanya itu.

2. Prinsip Memelihara Jiwa

Prinsip memelihara jiwa merupakan salah satu prinsip Maqasid Syariah yang berhubungan dengan perlindungan hak asasi manusia, yakni hak untuk hidup. Prinsip ini melandasi ketentuan bahwa setiap orang berhak untuk hidup, mempertahankan hidup dan meningkatkan taraf kehidupannya; bahwa setiap orang berhak hidup tenteram, aman, damai, bahagia, sejahtera, baik lahiriah 
maupun batiniah; dan bahwa setiap orang berhak atas rasa aman dan tenteram serta berhak atas perlindungan terhadap ancaman ketakutan.

3. Prinsip Memelihara Akal

Prinsip Memelihara Akal merupakan salah satu prinsip Maqasid Syariah yang berkait erat dengan perlindungan hak asasi manusia. Prinsip ini melandasi ketentuan bahwa setiap orang berhak memperoleh pendidikan. Prinsip ini melandasi ketentuan bahwa setiap orang berhak untuk mengembangkan dan memperoleh manfaat dari ilmu pengetahuan dan teknologi, seni, dan budaya sesuai dengan martabat manusia demi kesejahteraan pribadinya, bangsa, dan umat manusia; bahwa setiap orang berhak untuk berkomunikasi dan memperoleh informasi yang diperlukan untuk mengembangkan diri pribadi dan lingkungan sosialnya. Prinsip ini juga melandasi ketentuan bahwa setiap orang bebas untuk memilih dan mempunyai keyakinan politiknya; bahwa setiap orang bebas mempunyai, mengeluarkan dan menyerbarluaskan pendapat sesuai hati nuraninya, secara lisan dan tulisan.

\section{Prinsip Memelihara Keturunan}

Prinsip memelihara keturunan merupakan salah satu prinsip Maqasid Syariah yang relevan dengan perlindungan hak asasi manusia. Prinsip ini melandasi ketentuan bahwa setiap orang berhak membentuk suatu keluarga dan melanjutkan keturunan melalui perkawinan yang sah; bahwa setiap orang berhak atas perlindungan keluarganya dan kehormatannya.

\section{Memelihara Harta}

Prinsip memelihara harta merupakan salah satu prinsip Maqasid Syariah yang terkait dengan perlindungan juga terkait dalam perlindungan yang menyangkut hak asasi manusia. Prinsip ini melandasi ketentuan bahwa setiap orang berhak mempunyai milik, baik secara sendiri maupun bersama-sama dengan orang lain demi pengembangan dirinya, keluarga, bangsa dan masyarakat dengan cara yang tidak melanggar hukum; bahwa tidak seorangpun boleh dirampas miliknya dengan sewenang-wenang dan secara melawan hukum; dan bahwa setiap orang berhak atas perlindungan hak miliknya. 


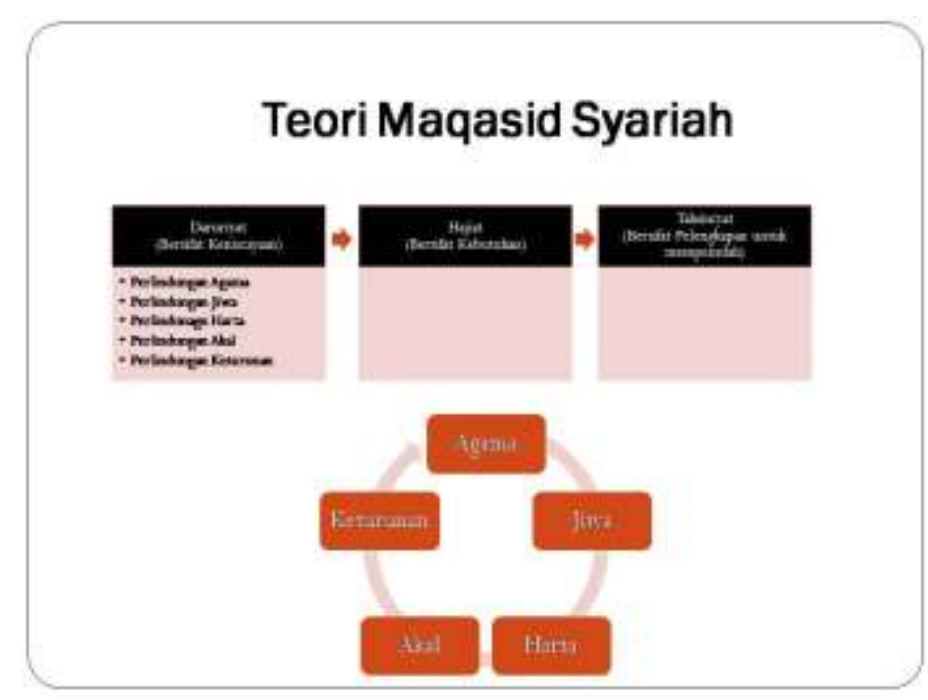

(Gambar 3) Kerangka Kerja Teori Maqasid Syariah

Gambar diatas tersebut mengilustrasikan bahwa dalam pembahasan teori maqasid syariah mempunyai tiga sifat yaitu pertama, sifat Daruriat (keniscayaan), kedua, sifat Hajiat (kebutuhan), ketiga sifat Tahsiniyat (kelengkapan). Dalam hal ini kebutuhan yang bersifat Daruriat itu mutlak harus dilakukan dalam menentukan tindakan, sedangkan kebutuhan yang bersifat Hajiat itu menjadi pelengkap serta kebutuhan Tahsiniyat menjadi perisai untuk memperindah.

Dalam proses pembangunan nilai pada Piagam Madinah menurut penulis sejalan dengan teori maqasid syariah yang berkaitan dengan sifat Daruriat (keniscayaan) dengan mengedepankan terhadap perlindungan mutlak kepada lima hal yaitu perlindungan terhadap agama, perlindungan terhadap jiwa, perlindungan terhadap harta, perlindungan terhadap akal, dan perlindungan terhadap keturunan, sebagaimana penulis telah jelaskan diatas.

\section{KESIMPULAN}

Penelitian mengenai Dogma dan Politik dalam Piagam Madinah, menyimpulkan beberapa hal :

1. Perbedaan agama, suku, golongan, etnisitas dan status sosial terlebur dalam konsep Human Equality (persamaan hak kemanusiaan) yang dibawakan oleh Muhammad SAW dalam suatu kesatuan yang disebut Ummah (umat) dengan prinsip perlindungan terhadap agama (hifzuddin), perlindungan terhadap jiwa 
(hifzun-nafsi), perlindungan terhadap harta (hifzulmali), perlindungan terhadap akal (hifzul-aqli), perlindungan terhadap keturunan (hifzun-nasli).

2. Nilai-nilai yang menjadi pijakan masyarakat dalam pembentukan Piagam Madinah menjadi suatu konstitusi dalam masyarakat Madinah yang dibawakan oleh Muhammad SAW adalah Nilai Humanism (kemanusiaan), Equality (persamaan) dan Justice (keadilan).

3. Masyarakat Madinah sebelum adanya Piagam Madinah merupakan masyarakat yang heterogen dengan perbedaan agama, suku, golongan, dan status sosial yang dilanda kekacauan sosial politik dengan perselisihan, perang saudara atau perang antar suku menjadi pemandangan yang biasa dalam masayarakat Madinah. oleh karena itu Muhammad SAW membangun wawasan kebangsaan dalam Piagam Madinah dengan konsep kesatuan Ummah, dimana masyarakat mempunyai kepercayaan ketuhanan, dan membangun persamaan berpolitik akan kebersamaan kehidupan berbangsa dan bernegara yang disebut Ummah dalam Piagam Madinah.

\section{DAFTAR PUSTAKA}

A. H. Maslow, "A Theory of Human Motivation," Phsychologicol Review, No. 50 .1943 .

Abu Faris, Muhammad 'Abd Qadir. Al-Nizam al-Siyasiy fil-Islam, terj. Musthalah Maufur, Sistem Politik Islam. Jakarta: Robbani Press, 2000.

Ahmad, Barakat. Muhammad and the Jews. New Delhi: Vikas Publishing House PVT LTD, 1979.

al-Din al-Rayis, Muhammad Dhiya'. al-Nazhariyyat al-Siyasat al-islamiyyatt, Maktabat al-Anjlu, Mesir, 1957

al-Din al-Tufi, Najm. al-Tayin fi Syarh al-Arba'in. Beirut: al-Rayyan, 1419 H.

Ali Engineer, Asghar. Islam dan Pembebasan. Yogyakarta: LKiS, 1993.

al-Jauziyyah, Ibn Qayyim. Zad al-Ma ad fi Hadyi Khair al- 'lbad. Kairo: Maktabah al-Qayyimah, 1989.

al-Juwaini, Abdul-Malik. Ghiyas al-Umam fi Iltiyas al-Zulam. ed. 'Abdul 'Azim al-Dib. Qatar: Wazarah al-Syu'un al-Diniyyah, $1400 \mathrm{H}$. 
al-Maliki ibn al-'Arabi, Abu Bakr. Al-Mahsul fi Usul al-Fiqh, ed. Husayn 'Ali Alyadri dan Sa'id Fuda, edisi ke-I. 'Amman: Dar al-Bayariq, 1999.

al-Qaradawi, Yusuf. Kayfa Nata'amal Ma'a at-Qur'an al-'Azim? edisi ke-I. Kairo: Dar al-Syuruq, 1999.

al-Salih, Subhi. 'Ulum al-Hadls wa Mustalahuh. Beirut: Dar al-Tlm lilMalayin, cet. 9, 1977.

al-Tahir ibn Ashur, Mohammad. Ibn Asyur, Treatise on Moqasid al-Syari'ah, terjemahan Muhammad el-Tahir el-Mesawi. London, Washington: International Institute of Islamic Thought (HIT), 2006.

Al-Tahir ibn Asyur, Muhammad. Usul al-Nizam aNjtimal fi al-Islam, ed. Muhammad el-Tahir el-MeSaw.i 'Amman: Dar al-Nafa'is, 2001.

Amin, Ahmad. Fajr al-Islam. Kairo: Maktabah al-Nahdah al-Misriyyah, 1979.

Auda, Jasser. Membumikan Maqasid Syariah Melalui Hukum Islam. Bandung: Mizan Pustaka, 2015.

Azhari, M. Tahir. Negara Hukum; Suatu Studi tentang Prinsip-prinsipnya Dilihat dari Segi Hukum Islam, Implementasinya pada Periode Negara Madinah dan Masa Kini. Jakarta: Bulan Bintang, 1992.

Babcock, Philip. Gove, et. al., (eds), Webster's Third New International Dictionary of the English Language, G \& G Merriam Company, Massachusets, 1961.

Bashori, H. M. As'ad. SejarahKebudayaan Islam. Surabaya: Prima Media, 2008.

Behn, Wolfgang. Muhammad and The Jewes of Medina, terjemahan dari Mohamed en de Joden te Medina, oleh Arent Jan Wensinck. Berlin: Klaus Schwarz Verlag-Freiburg Im Breisgou, 1975.

Budiardjo, Miriam. Dasar-Dasar Ilmu Politik. Jakarta: PT. Gramedia Pustaka Utama, 1991.

Bulac, Ali. "Piagam Madinah," dalam Charles Kurzman (ed.), Liberal Islam: A Sourcebook.terj. Bahrul Ulum dan Heri Junaidi, Wacana Islam Liberal; Pemikiran Islam Kontemporer tentang Isu-isu Global. Jakarta: Paramadina, 2001.

Burkle, Howard R. "Theocracy", dalam The World Book Encyclopaedia, Vol. 9, World Book, Inc., London, 1986. 
Chilcote, Ronald H. Teori Perbandingan Politik: Penelusuran Paradigma, alih bahasa Haris Munandar dan Dudy Priatna, Jakarta: Rajawali Pers, 2010.

D. Wallace, Dewey. 'Theocracy", dalam Mircea Eliade, (ed.), The Encyclopaedia of Religion, Vol. 14, MacMillan Company, New York, 1987.

E. Apter, David. The Politics of Modernization. Chicago: The University of Chicago Press, 1969.

Esposito (ed)., Jhon L. Ensiklopedi Dunia Islam Modern. Bandung: Mizan, 2001.

Fowler H. W. and F.G. Fowler. The Concise Oxford Dictionary of Current English, Oxford at The Clarendon Press, London, 1952.

Gibb, H.A.R. Muhammadanism An Historical Survey, Oxford University Press, London, 1949.

Hamidullah, M. The First Written-Constitution in the World. India: Hyderabad Deccan, 1983.

Harun, Tahzlb 'Abd al-Salam. Sirah ibn Hisyam. Beirut: Dar al-Buhus al'Ilmiyyah, 1979.

Hasan, Hasan Ibrahim. Tarikh al-Islam. Kairo: Maktabah al-Nahdah al-Misriyyah, 1979.

Hilmi, Mahmud. Nizam al-Hukm al-Islamiy Muqaranan bin-Nuzum al-Mu'sirah. Kairo: Dar al-Huda, cet. 4, 1978.

Husain Haikal, Muhammad. Hayatu Muhammad. Kairo: Dar Ma'arif, cet. 14, t.t.

Husein Nasution, Amin dan M. Iqbal. Pemikiran Politik Islam dari Masa Klasik hingga Indonesia Kontemporer. Jakarta: Kencana, 2010.

Ibn Hisyam, Muhammad. Sirah al-Nabiy. Kairo: Dar al-Sahabah lit-Turas, 1995.

Ibn Ishaq, Muhammad. Al-Sirah al-Nabawiyyah. Beirut: Dar al-Kutub alTlmiyyah, 2004.

Iqbal, Muhammad. Fiqh Siyasah; Kontekstualisasi Doktrin Politik Islam (Jakarta: Gaya Media Pratama, 2001.

Ismatullah, Deddy dan Asep A. Sahid Gatara, Ilmu Negara dalam Multi Perspektif; Kekuasaan, Masyarakat, Hukum dan Agama. Bandung: Pustaka Setia, cet. 2, 2007.

Isywara, F. Pengantar Ilmu Politik. Bandung: Bina Cipta, cet. 7, 1980. 
Jalal Syaraf, Muhammad dan'Ali'Abd al-Mu'thi Muhammad, al-Fikr al-Siyasi fi' al-Islam, Dar al-Jami' al-Mishriyyat, Iskandariyyat, 1978.

Jamal al-DIn Muhammad bin Mukram ibn Manzur, Abu al-Fadl. Lisan al-'Arab. Beirut: Dar al-Sadir, 1992.

Jugaym, Nu'man. Truq at-Kasyf an Maqasid al-Syari'ah (International Islamic University, Malaysia. Dipublikasikan oleh Dar al-Nafa'is, 2002.

K. Hitti, Philip. History ofArabs. London: Macmillan, cet. 10, 1990.

Koenjaraningrat, Metode Penelitian Bidang Masyarakat. Jakarta: Gramedia, 1989.

Lambton, Ann K.S. State and Government in Medieval Islam, Oxford University Press, London, 1981.

Lings, Martin. Muhammad. Jakarta: Serambi, 2007.

Madjid, Nucholish. Islam Agama Peradaban; Membangun Makna dan Relevansi Doktrin Islam dalam Sejarah. Jakarta: Paramadina, cet. 3,2008.

Madjid, Nurcholish . Islam Agama Peradaban; Membangun Makna dan Relevansi Doktrin Islam dalam Sejarah. Jakarta: Paramadina, cet. 3, 2008.

Madjid, Nurcholish. "Cita-Cita Politik Kita" dalam Basco Carvallo dan Dasrizal, (eds.), Aspirasi Umat Islam Indonesia, Leppenas, Jakarta, 1983.

Moleong, Lexy J. Metodologi Peneitian Kualitatif, cet. ke-31. Bandung: PT. Remaja Rosdakarya, 2013.

Mudzhar, M. Atho'. Membaca Gelombang Jihad: antara Tradisi dan Liberalisasi. Yogyakarta: Titihan Ilahi Press. 1998.

Muhammad ibn Isma'Il ibn Ibrahim ibn al-Mugirah ibn Bardazbah al-Bukharl, Abu Abdullah. Sahih al-Bukharl. Kairo: Dar al-Hadls, 2004.

Nasution, Harun. Islam Ditinjau dari Berbagai Aspeknya. Jakarta: UI Press, cet. $5,1985$.

Noer, Deliar. Pemikiran Politik di Barat. Rajawali, Jakarta, 1982

Pohan, Rahmd Asril. Toleransi Inklusif : Menapak Jejak Sejarah Kebebasan Beragama dalam Piagam Madinah. Yogyakarta: Kaukaba Dipantara, 2014.

Prodjodikoro, Wirjono. Asas-Asas Ilmu Negara dan Politik, PT Eresco, BandungJakarta, 1981. 
Pulungan, J. Suyuti. Prinsip-prinsip Pemerintahan dalam Piagam Madinah ditinjau dari pandangan al-Qur'an. Jakarta : RajaGrafindo Persada, 1996.

Rahman, FazIur . "The Islamic Concept of State", dalam John J. Donohue and L. Esposito, (eds.), Islam inTransition, Muslim Perspective, Oxford University Press, New York, 1982.

Rasjidi, M. Koreksi Terhadap Drs. Nurcholish Madjid Teniang Sekularisme, Bulan Bintang, Jakarta, 1972.

Ratna, Nyoman Kutha. Teori, Metode, dan Teknik Penelitian Sastra, cet. Ke-2. Yogyakarta: Pustaka Pelajar 2006.

Rosid, Muhammad. Strategi Komunikasi Politik dalam Pilkada (Studi Kasus Kemenangan Pasangan Kandidat Ratu Atut dan Rano Karno. Jakarta: Universitas Indonesia, 2012.

Sarankos, Satrios. Sosial Research. Melborn: Mac Milan Education Australia Pty Ltd, 1993.

Smylie, James H. "Theocracy" dalam The Encyclopaedia Americana, Vol. 26, Grolier Incorporated, Denburg, Connecticut USA, 1985.

Soekanto, Soerjono. Sosiologi Suatu Pengantar. Jakarta: Rajawali, 1982.

Sudrajat, Budi. Sejarah Kebudayaan Islam. Jakarta: Yudhistira, 2007.

Sukardja, Ahmad. Piagam Madinah dan Undang-Undang Dasar 1945: Kajian Perbandingan tentang Dasar Hidup Bersama dalam Masyarakat yang Majemuk. Jakarta : Penerbit Universitas Indonesia (UI-Press), 1995.

Syalabl, Ahmad. Mausu 'ah al-Tarlkh al-Islamiy wal-Hadarah al-Islamiyah. Kairo: The Renaissance Bookshop, cet. 8. 1978.

Syihab al-Din al-Qarafi, al-Zakhirah (Beirut: Dar al-'Arab, 1994), vol. 5, hlm. 478

von Jhering, Rudolf. Law as a Means to an End (Der Zweck im Recht), terjemahan Isaac Husik, edisi ke-2 (New Jersey The Lawbook Exchange (Pada mulanya dipublikasikan pada 1913 oleh Boston Book Co), 2001.

Watt, W. Montgomery. Muhammad at Medina. London: Oxford University Press, 1972. 
Jurnal Keislaman, Vol. 1, No. 1, Maret

Watt, W. Montgomery. Muhammad at Medina. London: Oxford University, 1956.

Watt, W. Montgomery. Muhammad Prophet and Statesman. London: Oxford University Press, 1969. 